\title{
Mouse Tumor Gene Index
}

National Cancer Institute

\section{Source}

National Cancer Institute. Mouse Tumor Gene Index. NCI Thesaurus. Code C15976.

A component of CGAP. 